\title{
POLIGAMI DAN SANKSINYA MENURUT PERUNDANG-UNDANGAN NEGARA-NEGARA MODERN
}

\author{
Muhibbuthabry \\ Fakultas Tarbiyah dan Keguruan UIN Ar-Raniry Aceh \\ Jl. Syeikh Abdul Rauf Kopelma Darussalam Banda Aceh \\ E-mail:muhib_nett@yahoo.com
}

\begin{abstract}
Polygamy and the Punishment in the View of the Legislation of Modern Countries. One of the interesting themes of Islamic family law reform is the legal status of polygamy. Almost all Muslim countries make efforts to narrow the space for the practice of polygamy by providing sanctions for the doers, including Tunisia, Pakistan, Egypt, Syria, Malaysia, and Indonesia. This article tries to discuss and analyze this case by making a comparison between the laws of family law in some countries—such as Tunisia, Pakistan, Egypt, Syria, Malaysia, and Indonesia—and the concept of classical fiqh. The study shows that even though each of these countries has the same spirit of renewal, they practice different reform issues related to polygamy. It can be clearly seen in the diversity of forms of sanctions for the doers of polygamy.
\end{abstract}

Keywords: polygamy, law, modern nations

\begin{abstract}
Abstrak. Poligami dan Sanksinya Menurut Perundang-undangan Negara-negara Modern. Salah satu tema reformasi hukum keluarga Islam yang menarik untuk diamati adalah status hukum poligami. Hampir seluruh negaranegara Muslim melakukan upaya mempersempit ruang bagi praktik poligami dengan memberikan sanksi bagi para pelakunya, termasuk Negara Tunisia, Pakistan, Mesir, Syria, Malaysia, dan Indonesia. Artikel ini mencoba membahas dan menganalisis dengan melakukan perbandingan antara undang-undang hukum keluarga di Tunisia, Pakistan, Mesir, Syria, Malaysia, dan Indonesia, dengan konsep fikih klasik. Studi ini mencatat, meski sama-sama didasari oleh semangat pembaruan, masing- masing negara ini melakukan praktik pembaruan yang berbeda-beda terkait isu poligami. Hal ini tampak dari keragaman bentuk sanksi yang diberikan kepada para pelaku poligami.
\end{abstract}

Kata kunci: poligami, perundang-undangan, negara-negara modern

\section{Pendahuluan}

Hampir seluruh dunia Islam sekarang sedang bergerak ke arah pembaruan hukum Islam. Genderang itu mulai ditabuh pada awal abad XX yang membawa negara-negara Muslim ke arah kehidupan hukum yang lebih baik. Demikian pula halnya dengan hukum keluarga Islam yang disebut-sebut sebagai inti syariat. ${ }^{1}$ Pembaruan di bidang ini berimplikasi luas pada tatanan keluarga ke arah remedialisme, bahkan lebih jauh pada tatanan hidup berbangsa dan bernegara.

Lokomotif hukum keluarga adalah Turki, ketika negara ini menerbitkan Ottoman Law of Family Right, kemudian diikuti negara-negara Islam lain. Secara umum, substansi undang-undang hukum keluarga di dunia Islam

Naskah diterima: 24 Juli 2015, direvisi: 4 Oktober 2015, disetujui untuk terbit: 10 November 2015.

1 Antony Allat, "Introduction," dalam Chibi Mallat dan Jane Cannors (ed), Islamic Family Law, (USA: Graham and Rotman, 1990), h. xi- xiii. modern telah beranjak dari konstruksi wacana fikih klasik dan telah mencoba memecahkan persoalan-persoalan ketimpangan hak antara laki-laki dan perempuan dalam keluarga sehingga hak-hak perempuan dalam perkawinan (marital right) diakui. ${ }^{2}$

Salah satu tema reformasi hukum keluarga Islam yang menarik untuk diamati adalah status hukum poligami. Hampir seluruh negara Islam melakukan upaya mempersempit terjadinya poligami, ${ }^{3}$ Syria melakukan hal itu sejak tahun 1953, Pakistan sejak tahun

\footnotetext{
${ }^{2}$ Tahir Mahmood, Personal Law in Islamic Countries, (New Delhi: Academi of Law and Relegion, 1987), h. 12.

${ }^{3}$ Istilah poligami atau poligini adalah suatu isu kontroversial di negara-negara Islam modern. Sebelum kedatangan Islam, poligami lebih awal dipraktikkan oleh masyarakat Mesopotamia. Secara historis, dua golongan Islam telah mempraktikkan juga sejak awal, yaitu golongan Suni dan Syiah. Namun, dalam perkembangannya, beberapa negara berkembang melarang praktik ini, berkaitan dengan pertimbangan dan kepentingan suatu negara dalam menata setting sosialnya. John L. Esposito, The Oxford Encyclopedia of the Modern Islamic World, (New York: Oxford University Press, 1995), h. 335-336.
} 
1961 dan Indonesia sejak tahun 1974, bahkan di Turki sejak 1926 poligami resmi dilarang. Di Tunisia seperti di Turki, poligami juga dilarang dengan UU tahun 1956, bahkan bagi yang melanggar dikenakan hukum dengan pelbagai bentuknya sesuai dengan undang-undang dari negara-negara tersebut. ${ }^{4}$ Upaya ini adalah reaktualisasi hukum Islam yang mapan dalam kitab-kitab fikih. Isu selama ini ialah begitu mudah memberikan izin poligami dan karenanya terkadang disalahgunakan sehingga menjadi sumber kesengsaraan sebagian wanita. ${ }^{5}$

Pelbagai upaya modernisasi hukum telah banyak dilakukan di pelbagai negara Muslim, namun pembaruan yang dilakukan negara-negara tersebut belum seluruhnya merata. Isu ini dapat di lihat pada negara Turki yang secara tegas menyatakan diri sebagai negara sekuler yang merupakan negara yang paling awal mengadakan pembaruan di bidang hukum keluarga.

Lain halnya Tunisia, sekularisasi hukum telah mengalami perubahan yang cukup radikal. Bahkan elit politik berupaya untuk mengikis peran agama secara menyeluruh. Demikian halnya Pakistan, para elit politik menjadikan Islam bagian dari politik untuk menghindari konflik dalam menghadapi sikap kelompok yang mendukung diberlakukannya undangundang syariat.

Isu poligami tidak lepas dari persoalan di atas, tarikmenarik antara pemuja Barat dan pihak yang tetap konstan pada tradisi fikih konservatif memperpanjang isu poligami sampai sekarang. Sesuai referensi yang ada, pembaruan undang-undang poligami di negaranegara Muslim tidak menunjukkan perkembangan yang cukup dramatis. Sebagai negara radikal, hanya Turki dan Tunisia yang mempunyai kebijakan berbeda dengan negara lain, keduanya berani melarang praktik poligami bagi penduduknya bahkan ditetapkan sanksinya.

Penyebab utama terjadinya kebijakan dari negara yang dimaksudkan di atas adalah tidak lepas dari situasi sosial politik yang melingkupinya. Penulis mencoba mendeskripsikan pada ketentuan poligami yang berlaku di negara masing-masing dengan melihat keterkaitan mazhab fikih yang dianut masing-masing negara, baik secara horisontal, vertikal, maupun secara diagonal.

${ }^{4}$ M. Atho Mudzhar, "Letak Gagasan Reaktualisasi Hukum Islam Munawir Syadzali di Dunia Islam”, dalam Kontekstualisasi Ajaran Islam 70 Tahun Munawir Syadzali, (Jakarta: Paramadina, 1995), h. 318.

${ }^{5}$ M. Atho Mudzhar, "Letak Gagasan Reaktualisasi Hukum...”, h. 319.

\section{Poligami dalam Hukum Islam}

Poligami merupakan institusi problematis dalam Islam, poligami diartikan sebagai perkawinan yang lebih dari satu, tetapi disertai dengan sebuah batasan, yaitu diperbolehkan hanya sampai empat orang wanita karena ada indikasi nash. Argumentasi yang sering dijadikan dasar kebolehan poligami dalam Islam adalah firman Allah ${ }^{6}$,

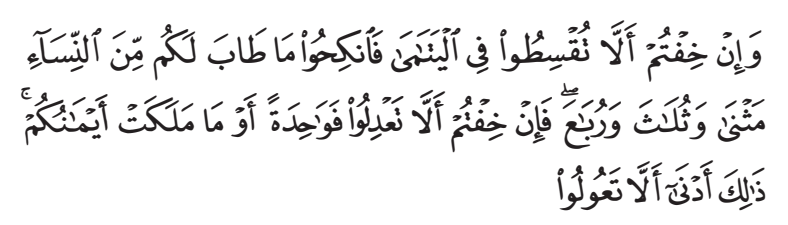

Dan jika kamu takut tidak akan dapat berlaku adil terhadap (hak-hak) perempuan yang yatim (bilamana kamu mengawininya), maka kawinilah wanita-wanita (lain) yang kamu senangi: dua, tiga atau empat. Kemudian jika kamu takut tidak akan dapat berlaku adil, maka (kawinilah) seorang saja, atau budak-budak yang kamu miliki. Yang demikian itu adalah lebih dekat kepada tidak berbuat aniaya.

Bertitik tolak dari ayat ini, Rasulullah Saw. melarang seorang pria menghimpun lebih dari empat orang istri pada saat yang sama. Ketika ayat itu turun, Rasulullah Saw. memerintahkan setiap pria yang memiliki lebih dari empat orang istri agar segera menceraikan istriistrinya sehingga maksimal seorang pria hanya memperistrikan empat orang wanita. Ketentuan ini ditegaskan melalui ucapannya, "Kami diberikan oleh Yahyâ ibn Hâkim, kami diberikan Muhammad ibn Ja'far, kami diberikan Mu'ammar dari al-Zuhrî, dari Sâlim, dari Ibn 'Umar berkata, Ghilan ibn Salâmah masuk Islam dan dia memiliki 10 istri, maka Nabi Saw. bersabda, ambillah dari mereka (istri-istrimu) empat orang"?

Keharusan berbuat adil di antara para istri menurut al-Syâfi'i, berhubungan dengan urusan fisik, misalnya mengunjungi istri di malam atau siang hari. Tuntutan ini didasarkan pada perilaku Nabi Saw. dalam berbuat adil kepada para istrinya, yakni dengan membagi giliran malam dan memberikan nafkah. ${ }^{8}$ Keadilan dalam hati, menurut al-Syâfiî hanya Allah

\footnotetext{
${ }^{6}$ Ayat ini adalah keharusan seorang suami yang berpoligami harus berlaku adil terhadap para istrinya dan sekaligus menjadi hak istri (Q.s. 4: 3). Ketika berbicara tentang hak kewajiban suami dan istri, al-Kasani (w. 587/1991) dari mazhab Hanafi, menulis tentang kewajiban suami dan berpoligami, yaitu wajib berlaku adil terhadap istri-istrinya, dan sekaligus menjadi hak istri, dalam Al-Imâm 'Alau al-Dîn Abî Bakr ibn Mas'ud al-Kasani, Kitâb Babâi'u al-Sanai’u fi Tartîb al-Sharanî, cet. I (Beirut: Dâr al-Fikr, 1996), h. 491.

${ }^{7}$ Hadis ini dapat dilacak dalam H.r. Malik, al-Nasải. dan al-

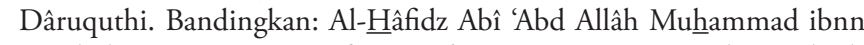
Yazid al-Quzwinî, Sunan Ibn Mâjah, Juz I, (Beirut: Dâr al-Qurub al'Ilmiah, t.th), h, 628.

${ }^{8}$ Al-Syâfi'î, al-'Umm, V: 172-173.
} 
yang mengetahuinya karena itu mustahil seorang dapat berbuat adil kepada istrinya yang diisyaratkan pada ayat $4: 129,{ }^{9}$

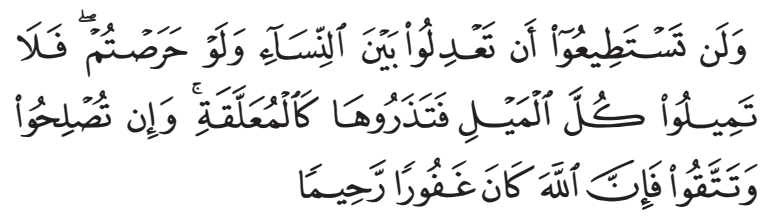

Dan kamu sekali-kali tidak akan dapat berlaku adil di antara istri-istri(mu), walaupun kamu sangat ingin berbuat demikian, karena itu janganlah kamu terlalu cenderung (kepada yang kamu cintai), sehingga kamu biarkan yang lain terkatung-katung. Dan jika kamu mengadakan perbaikan dan memelihara diri (dari kecurangan), maka sesungguhnya Allah Maha Pengampun lagi Maha Penyayang.

Dengan demikian, hati memang tidak mungkin berbuat adil. Sementara keharusan adil yang dituntut apabila seseorang mempunyai istri lebih dari satu adalah adil dalam bentuk fisik, yaitu dalam perbuatan dan perkataan. Keadilan dalam urusan fisik ini juga dituntut oleh ayat-ayat al-Ahzab (33: 50), al-Baqarah (2: 228), dan al-Nisa' (4: 19) ${ }^{10}$

Ibnu Qudamah dari mazhab Hambali berpendapat, seorang laki-laki boleh menikahi wanita maksimal empat. Hal ini dapat dilihat kasus Ghailan ibn Salamah dan kasus Nawfal bin Mu'âwiyah. Oleh karena itu, pembahasan ini menyimpulkan bahwa meskipun menggunakan dalil yang berbeda para ulama tradisional tersebut mengakui boleh poligami. Lebih lanjut disimpulkan bahwa ada sejumlah nash yang berhubungan dengan poligami yang dicatat para ulama mazhab, yaitu: al-Nisâ’: 3, al-Nisẩ 129, al-Ahhzâb: 50, al-Mủminûn: 5-6, ancaman bagi suami yang tidak adil kepada istri-istrinya, dan kasus laki-laki yang masuk Islam dan disuruh Nabi Saw. untuk mempertahankan istrinya maksimal empat. Semua nash inilah yang membahas tentang poligami.

Secara tekstual, ayat-ayat dan hadis di atas merupakan dasar hukum kebolehan berpoligami. Namun, seperti dijelaskan M. Quraish Shihab makna ayat tersebut sering disalahpahami. Lebih lanjut, ia menjelaskan bahwa ayat itu turun menyangkut sikap sebagian orang yang ingin mengawini anak-anak yatim kaya dan cantik yang berada di dalam pemeliharaannya, tetapi tidak ingin memberikannya mas kawin yang sesuai serta

${ }_{9}$ Q.s. 4: 129. Dan kamu sekali-kali tidak akan dapat berlaku adil di antara istri-istrimu, walaupun kamu sangat ingin berbuat demikian, karena itu janganlah kamu terlalu cenderung (kepada yang kamu cintai), sehingga kamu biarkan yang lain terkantung-kantung. Dan jika kamu mengadakan perbaikan dan memelihara diri (dari kecurangan), maka sesungguhnya Allah Maha pengampun lagi Maha Penyayang.

${ }^{10}$ (Dan bergaullah dengan mereka secara patut) tidak memperlakukannya secara adil. ${ }^{11}$

Dalam perspektif hukum Islam, poligami merupakan isu yang sangat kontroversial karena menimbang beberapa hal. Pertama, Nabi Muhammad Saw. sendiri melakukan praktik poligami. Kedua, adanya sistem pergundikan dalam Islam, di mana seorang Muslim pada masa lampau dapat bergabung seks dengan budak perempuannya. Ketiga, ayat Alquran yang membicarakan poligami merupakan ayat mutasyâbih sehingga kesamarannya dapat menimbulkan tafsiran yang beragam. ${ }^{12}$ Bahkan praktik poligami telah lama dikukuhkan dalam tradisi agama-agama kuno. ${ }^{13}$

Indikasi diperbolehkanya berpoligami sangat sulit dipraktikkan karena tidak semua pria dapat memenuhi persyaratan keadilan sebagaimana ditegaskan Alquran, "Dan kamu sekali-kali tidak akan dapat berlaku adil di antara istri-istrimu walaupun kamu sangat ingin berbuat demikian". ${ }^{14}$

Fenomena dua ayat tersebut oleh Leila Ahmed dipersepsikan sebagai sikap ambiguitas dan kompleksitas instrinsik dalam ayat poligami. Di satu sisi, Alquran memberi peluang bagi poligami, sementara jika merasa mampu berbuat adil, sementara di sisi lain sekaligus mendeklarasikan bahwa manusia tidak akan mampu berbuat adil, di mana ketidakmampuan tersebut diformulasikan dalam bahasa Arab yang mengindikasikan sebuah ketidakmungkinanyang permanen. ${ }^{15}$ Semangat inilah sebenarnya, menurut Rahman yang mendasari negara-negara Muslim dalam melakukan pembaruan hukum keluarganya. ${ }^{16}$

Solusi paling tepat yang dapat diterima semua kalangan, masih menurut Rahman adalah poligami dalam Alquran dalam terdapat dua level. Pertama, legal level,di mana poligami terbatas (sampai empat) dibolehkan, dan kedua, moral level, di mana Alquran kelihatannya menginginkan agar masyarakat bergerak dalam diskursus waktu itu. ${ }^{17}$

Berbeda dengan Anderson, ia memilih pandangan

${ }^{11}$ M. Quraish Shihab, Wawancara al-Qur'an, (Bandung: Mizan, 1997).

12 Rubya Mehdi, The Islamization of The Law In Fakistan, (Richmond: Curzon Press, 1994), h. 161.

${ }^{13}$ James Hesting, Dictionary of Bible, (New York: Charles Scribner's Sons, 1963), h. 624.

${ }^{14}$ Pernyataan ini termatub dalam Q.s. 4: 129.

${ }^{15}$ Leila Ahmed, Women and Gender in Islam, Historical Roots of a Modern Debate, (London: Yale university Press, 1992), h. 63.

${ }^{16}$ Fazlur Rahman, "A Survey of Modernization of Muslim Family Law," dalam Internasional Journal Middle East Study, Vol. 11, (1980), h. 451-451.

${ }^{17}$ Fazlur Rahman, "A Survey of Modernization of Muslim Family Law," dalam Internasional Journal Middle East Study, Vol. 11, (1980), h. $451-451$. 
para ulama salaf, dengan alasan yang cukup masuk akal, mengatakan bahwa Alquran tidak dapat begitu saja dianggap bertentangan dengan dirinya sendiri. Oleh karena itu, keadilan yang dituntut oleh ayat poligami tersebut sebagai hal-hal yang dapat dilakukan atau diupayakan oleh suami. Jadi bukan merupakan perasaan batin atau rasa cintanya yang terdapat di dalam hati suami. ${ }^{18}$

Adapun menurut ijmak ulama, mengatakan bahwa sejak masa Nabi Saw. hingga saat ini kaum Muslimin sepakat, baik dalam ucapan maupun dalam perbuatan, kawin dengan batas maksimal empat orang. ${ }^{19}$ Namun sejarah mencatat lain, di mana mayoritas kitab tafsir merupakan produk wacana ulama pria sehingga memberikan bias bagi kaum perempuan. Oleh karena itu, reinterprestasi ulang dengan melihat kembali kepada sejarah sangat diperlukan guna memeriksa teksteks agama dan dokumen-dokumen fikih secara lebih kritis dan objektif. ${ }^{20}$

Bagaimana halnya kaum modernis memandang poligami? Pandangan dari pelbagai pemikir Muslim cenderung melarang poligami. ${ }^{21}$ Adapun yang cenderung melarang poligami adalah Muhammad Abduh, Fazlur Rahman, Fatimah Mernisi, Ali Asgar, dan Riffat Hasan. Dalam perspektif Abduh, poligami yang pada dasarnya tidak dilarang akan menjadi suatu institusi yang dilarang apabila orang yang berpoligami tidak mampu merealisasikan konsep adil dalam pelbagai dimensinya sebagaimana yang difirmankan dalam Alquran. ${ }^{22}$ Analisis lebih jauh dikemukakan bahwa jika yang dimaksud adil itu berarti hanya sebatas keadilan, dan persamaan dalam perlakuan lahiriah serta materi, maka Alquran tidak mungkin mengatakan bahwa suami mustahil dapat berlaku adil kepada istri-istrinya meskipun ia sangat menginginkannya. ${ }^{23}$

Melihat pendapat Rahman dengan gaya hermeneutik dan tafsir kontekstualnya ${ }^{24}$, maka umat Islam sekarang

18 J.N.D. Anderson, Islamic Law in Modern World, (London: Oxford University Press, 1995), h. 49.

${ }^{19}$ Jamal J. Nasir, The Statute of Women Under Islamic Law, (London Graham And Trotman, 1990), h. 24.

${ }^{20}$ Mai Yamani (ed), Feminisme dan Islam, diterjemahkan oleh Purwanto, (Jakarta: IKAPI, 2000), h. 1-3.

${ }^{21}$ Fazlur Rahman, "A Survey of Modernization of Muslim Family Law," dalam Internasional Journal Middle East Study, Vol. 11, (1980), h. $451-451$.

${ }^{22}$ Muhammad Imarah, Al-Imam Muhammad Abduh: Mujaddid AlIslam (ttp, 1981), h. 33.

${ }^{23}$ Fazlur Rahman, The Controversi Over Muslim The Family Law dalam South Asian Politics And Religions, (New Jersey: Princeton University Press, 1996), h. 416.

${ }^{24}$ Ada tiga aspek penting dalam menafsirkan ayat, yaitu: a). Dalam kontek apa ayat itu ditulis (jika dikaitkan dengan Alquran dalam konteks ayat itu diturunkan. b). Bagaimana komposisi bahasa teks tersebut ini terjebak pada legal spesific dari ayat poligami dengan menginterprestasikannya sebagai justifikasi poligami berdasarkan bunyi teks dan penafsiran ini yang di ke depankan. Sementara ieal moral dari ayat poligami tersebut justru dikesampingkan. Sebab ajaran murni Islam dalam perkawinan adalah monogami.

Adapun Amina Waduud berpendapat bahwa dalam hal poligami, ayat 4:3 merupakan solusi tepat agar para pengelola harta anak yatim tidak terjebak pada perbuatan tidak adil dengan cara menikahi anak yatim dan pernikahan itu dibatasi sampai empat. Jadi, jelaslah bahwa ayat itu turun dalam konteks keadilan dalam mengelola harta anak yatim dan keadilan kepada para istri karena rasio janda dan anak yatim meningkat sebagai akibat dari kekalahan perang. ${ }^{25}$

Berdasarkan pelbagai pendapat kontroversi tersebut, dapat dipahami bahwa Alquran hanya membolehkan dalam kondisi tertentu sebagai solusi untuk mengatasi kebuntuan kehidupan keluarga. Dalam kondisi seperti ini, poligami merupakan solusi ideal. Namun, hal itu sangat tergantung pada pertimbangan setiap Muslim. Artinya, poligami tidak merupakan anjuran apalagi perintah.

\section{Sanksi Poligami di Tunisia}

Tunisia merupakan negara modern berkenaan masalah hukum keluarga. Hal ini terbukti ketika negara-negara mayoritas Muslim menjalankan hukum keluarga secara tunduk sesuai dengan makna globalnya Alquran, negara ini secara modern mengambil langkah lain.

Sebelum melangkah pembahasan kepada hukum keluarga, seyogyanya diketahui bahwa di Tunisia, Islam memiliki pengaruh politik karena banyaknya dinasti ${ }^{26}$. Salah satunya adalah dinasti Fatimiyah yang bermazhab Syiah dan secara formal Tunisia berada di bawah kontrol Perancis. Pada saat itu, baik mazhab Hanafi maupun Maliki telah lama terkukuhkan. Setelah kemerdekaan tahun 1956, masyarakat menentang kemapanan agama melawan tradisi secara Islam dengan anggota Destour lama. Beberapa tahun setelah itu, pemerintah mengundangkan peraturan beberapa kali dan menjalankan gagasan lain yang bertujuan memper-

(pengungkapan dan apa yang dikatakannya). c). Bagaimana keseluruhan teks (ayat). Adapun metode double movement-nya, lihat Rahman, Islam and Modernity: Transformation of an Intellectual Tradition, (Chicago: The University of Chicago Press, 1982), h. 4-9.

${ }^{25}$ Amina Waduud Muhsin, Qur'an And Women, (Kuala Lumpur : Fajar Bhakti SDN, 1994), h. 82

${ }^{26}$ Jean Claude Vatin, Revival in the Magrib: Islam as an Alternative Political language, dalam Ali Hilal E. Dessouki, Islamic Resurgence in the Arab World, (USA: Praeger Publishers, 1982), h. 238. 
lemah posisi syekh dan ulama. Pengadilan agama ditekan, hukum dan pendidikan disatukan, dan ritual agama diawasi. ${ }^{27}$ Kemajuan sekulerisasi yang dijalankan tampaknya berhasil. Reduksi terhadap tradisional Islam dan kepentingan-kepentingannya diatur oleh negara. Setelah itu, adaptasi Islam mulai dijalankan melalui intervensi presiden untuk memudahkan jalannya modernisasi. Keadaan inilah turut mempengaruhi pandangan para legislator dalam mengadakan pembaruan di bidang hukum, terutama berbarengan dengan menguatnya isu poligami.

Sekularisasi yang terjadi di Tunisia sangat berbengaruh pada masyarakat banyak dalam menyahuti poligami. Praktik seorang laki-laki memiliki beberapa orang istri merupakan masalah yang problematik, krusial, dan kontroversial dalam masyarakat modern. Setelah dipengaruhi oleh pemikiran Barat, wacana perempuan dalam Islam menjadi kontroversi yang tidak ada hentinya di kalangan kaum Muslim terpelajar, ${ }^{28}$ yang memunculkan diskursus apakah poligami berlaku secara normatif atau kontekstual.

Berdasarkan hal tersebut, maka untuk mengambil wacana tentang pelarangan keras terhadap praktik poligami hendaknya menoleh kepada undang-undang poligami Tunisia pada Pasal 18 dengan tegas mengatakan:

1. Beristri lebih dari satu dilarang. Siapa saja yang telah menikah sebelum perkawinan pertamanya benarbenar berakhir, lalu menikah lagi akan dkenakan hukuman penjara selama satu tahun atau denda sebesar 240.000 malim atau terhadap keduakeduanya. ${ }^{29}$

2. Barang siapa yang telah menikah melanggar ketentuan dalam UU no. 3 Tahun 1957 yang berkaitan dengan aturan status sipil dan kontrak perkawinan kedua sementara ia hidup dengan istri pertama akan dijatuhi hukuman yang sama.

3. Seorang yang diketahui menikah dengan orang lain juga dikenakan hukuman yang sama. ${ }^{30}$

${ }^{27}$ Ira M. Lapidus, Sejarah Sosial Umat Islam, (Jakarta: Rafa Grafindo, 1996), h. 228.

${ }^{28}$ Raga’ El-Nimr, "Perempuan dalam Hukum Islam," dalam Mai Yamani (ed), Feminisme dan Islam, diterjemahkan oleh Purwanto, (Jakarta: IKAPI, 2000), h. 133.

${ }^{29}$ Tahir Mahmood, Personal Law in Islamic Countries History, Text and Comparative Analysis, (New Delhi: Academy of Law and Religion, 1987), h. 155-156. Lihat juga, M. Atho Mudzhar, The Status of Women in Islam and Muslim Societies (A Sociological Approach), Makalah Seminar Internasional "Islam and Humanism", IAIN Walisongo Semarang, 5 - 8 November 2000, h. 8.

${ }^{30}$ Tahir Mahmood, Personal Law in Islamic Countries History, Text and Comparative Analysis, (New Delhi: Academy of Law and Religion, 1987), h. 155. Secara tegas menungkapkan bahwa kalau perkawinan kedua dilangsungkan juga oleh seseorang, maka perkawinan itu batal demi hukum.
Semua ini adalah upaya reaktualisasi hukum Islam yang mapan dalam kitab-kitab fikih selama yang sebelumnya begitu mudah memberikan izin poligami. Hal itu terkadang disalahgunakan sehingga menjadi sumber kesengsaraan sebagian wanita. ${ }^{31}$

\section{Sanksi Poligami di Pakistan}

Undang-undang Pakistan menampakkan radikal dalam menyahuti keberanjakan- keberanjakan suatu hukum termasuk masalah perkawinan, khususnya poligami. Hal ini terbukti banyaknya pendapat yang bermunculan menentang gejala poligami dan menganggap merugikan pihak wanita dalam keluarga serta menghalangi kebebasan dan keleluasaanya. Oleh karena itu, isu ini mendapat tempat yang proporsional setelah kemerdekaan melalui perjuangan yang panjang.

Pernyataan di atas ditegaskan ordonansi tentang hukum keluarga Pakistan pada tahun 1961. Salah satu pasal yang memuatnya adalah pasal 6 Undang-undang Pakistan, ${ }^{32}$ yang menyatakan:

1. Selama masih terikat perkawinan, tidak seorang lelaki pun boleh melangsungkan perkawinan dengan orang lain kecuali telah mendapat izin tertulis dari dewan arbitrasi.

2. Permohonan izin pertama diserahkan kepada ketua dengan cara yan ditentukan sekaligus dengan biaya yang ditetapkan dan melampirkan alasanalasan untuk mengajukan perkawinan dengan menerangkan apakah izin dari istri telah diperoleh.

3. Dalam hal penerimaan permohonan ketua akan meminta kepada pemohon dan istri atau beberapa istrinya yang sah untuk mengajukan wakil masingmasing dan dewan arbitase akan memberi izin poligami apabila dewan memandang perkawinan tersebut perlu dan adil sesuai dengan pertimbangan kesehatan.

4. Dalam memutuskan permohonan tersebut, dewan mencatat alasan-alasan terhadap putusan tersebut dan pihak pemohonan boleh melebihkan surat permohonan untuk revisi surat keterangan tersebut dan menyerahkannya kepada klektor dan putusannya berlaku serta tidak akan dipertanyakan lagi di pengadilan.

5. Seseorang yang melakukan perkawinan dengan orang lain tanpa izin dari dewan arbitrase maka akan: Pertama: membayar seluruh mahar dengan segera kepada istri atau beberapa istrinya, baik tunai maupun ditangguhkan dan jika tidak membayar ia diperoleh dari tunggakan di atas sewa tanah. Kedua, dihukum penjara maksimal 1 tahun atau denda maksimal 5000 rupe atau kedua-duanya. ${ }^{33}$

${ }^{31}$ M. Atho Mudzhar, "Letak Gagasan Reaktualisasi Hukum Islam Munawir Syadzali di Dunia Islam", dalam Kontekstualisasi Ajaran Islam 70 Tahun Munawir Syadzali, h. 319.

${ }^{32}$ Tahir Mahmood, Family Law Reform in the Muslim Wold, (Bombay: N. M. Tripathi, 1972), h. 249.

${ }^{33}$ Tahir Mahmood, Personal Law in Islamic Countries History, Text 
Pasal ini menetapkan bahwa suami yang akan menikah lagi diperbolehkan asal mendapat izin dari dewan arbitrase. Di samping itu, suami harus mendapat izin dari istrinya yang sah, kecuali bila istri mendapat sakit gila, mandul, dan cacat fisik. Apabila tidak mendapat izin, tetapi perkawinan tetap dilaksanakan, maka ia dapat dikenakan hukuman penjara, atau denda sebagaimana dijelaskan.

\section{Sanksi Poligami di Mesir}

Usulan tentang pembahasan poligami dan hak cerai sepihak oleh suami selalu gagal di Mesir. Hal ini disebabkan adanya problem ekonomi dan kehidupan sosial yang meligkupinya. ${ }^{34}$ Pada draf UU No. 25 tahun 1920 misalnya, sudah dimasukkan dua pasal berhubungan dengan masalah poligami, yakni: (1). Bahwa seorang laki-laki yang ingin melakukan poligami harus terlebih dahulu mendapat izin dari pengadilan (hakim), dan (2) hakim hanya memberi izin kepada orang yang disetujui pasangan dan mampu menafkahi seluruh keluarga. Meskipun kedua pasal ini sudah disetujui oleh ulama yang masuk dalam panitia, tetapi harus dibuang dan tidak menjadi UU karena ada penolakan keras dari ulama-ulama lain. ${ }^{35}$

Kemudian draf yang sama diusulkan komite Mesir tahun 1927 untuk UU No. 20 tahun 1929, konon dipengaruhi oleh pemikiran Abduh bahwa untuk membatasi poligami adalah bukan saja boleh memasukkan pada taklik talak tentang hak cerai istri karena suami poligami, tetapi juga: (1). Seorang lelaki yang sudah beristri tidak boleh menikah lagi dengan wanita lain, dan pegawai pencatat tidak boleh mencatatkan pernikahan seperti ini tanpa ada izin pengadilan yang berwenang; (2) Hakim yang menangani seharusnya tidak memberi izin sebelum membuktikan bahwa; (1) Laki-laki yang bersangkutan mampu secara ekonomi menanggung seluruh keluarga dan (2) dapat berlaku adil (pada para istri dan anakanaknya). Aturan ini batal karena diveto Raja Fuad, tetapi diusulkan lagi tahun 1943 dan 1945, juga tidak diterima. ${ }^{36}$

Setelah tahun 1985, Mesir dengan UU (Amandemen

and Comparative Analysis, (New Delhi: Academy of Law and Religion, 1987), h. 243.

${ }^{34}$ Don Peretz, The Middle East Today, Edisi IV, (New York: Praeger, 1983), h. 262.

${ }^{35}$ Farhat J. Ziadeh, Lawyer: The Role of Law and Liberalism in Modern Egypt, (California: Stanford University, 1968), h. 126: Anderson, Law Reform in Muslim Word, (London: Athlone Press, 1976), h. 62.

${ }^{36}$ Anderson, Law Reform Law Reform in Muslim Word, (London: Athlone Press, 1976), h. 62 dan 110.
Law) No. 100 tahun 1985 menetapkan aturan poligami. Amandeman tersebut menentukan, poligami dapat menjadi alasan perceraian bagi istri dengan talik thalak atau tidak dengan alasan hal itu mengakibatkan kesusahan ekonomi. Di samping itu, pengadilan harus memberitahukan kepada istri atau istri-istrinya tentang rencana poligami tersebut. ${ }^{37}$ Bagi yang melanggar aturan ini dapat dihukum dengan hukuman penjara, atau denda, atau kedua-duanya. Adapun sanksinya adalah hukuman penjara maksimal enam bulan atau 200 pound Mesir atau kedua-duanya. Hal yang sama juga dikenakan untuk orang yang membuat pengakuan palsu kepada pengawai pencatat tentang status perkawinan atau alamat istri atau istri-istrinya, atau istri yang dicerainya karena bertentangan dengan pasal $11 \mathrm{~A}$. Seorang pegawai pencatat yang lalai atau gagal melakukan tugasnya dapat dihukum dengan hukuman penjara satu bulan dan hukuman denda maksimal 50 pound Mesir. Pegawai bersangkutan dinon-aktifkan selama maksimal satu tahun. $^{38}$

Hanya saja ada tidaknya masalah ekonomi dalam rumah tangga sebagai akibat dari poligami hanya diberi tenggang waktu selama satu tahun, sementara kalau sudah lewat waktu tersebut istri tidak berhak lagi menuntut perceraian dengan alasan tidak terpenuhinya kebutuhan ekonomi akibat poligami.

\section{Sanksi Poligami di Syria}

Hukum keluarga di Syria menampakkan watak yang radikal. Hal itu tercermin dari perombakan dalam mengatur tentang status perempuan, seperti poligami yang berlaku sepanjang tradisi dan legislasi penghapusan hak unilateral pihak suami yang menceraikan istrinya. Dalam kasus perceraian, hak suami dibatasi secara radikal dengan ketentuan bahwa seluruh perceraian harus melalui lembaga peradilan. Wanita dalam hal ini memperoleh hak yang setara dengan laki-laki sehingga berhak mengajukan tuntutan perceraian atas suaminya.

${ }^{37}$ Pasal 11A menjelaskan, "Seorang yang akan menikah harus menjelaskan status perkawinannya pada formulir pencatatan perkawinan. Laki-laki yang sudah beristri harus mencantumkan nama dan alamat istri atau istri-istrinya. Pegawai pencatat harus memberitahu istrinya tentang rencana perkawinan tersebut. Seorang istri yang suaminya menikah lagi dengan wanita lain, dapat meminta cerai berdasarkan kemudaratan ekonomi yang diakibatkan poligami sehingga tidak mungkin hidup bersama dengan suaminya. Hak cerai ini dapat berlaku baik ditetapkan atau tidak dalam ta'lik talak. Ketika hakim tidak berhasil mendamaikan, perceraian dapat terjadi. Hak istri minta cerai hilang dengan sendirinya kalau dia tidak memintanya selama masa satu tahun. Dawoud L. Alami dan Doreen Hinchcliffe, Islamic Marriage and Devorce Laws of Arab World, (London: Kluwer Law Internasional, 1996), h. 58.

${ }^{38}$ Tahir Mahmood, Personal Law in Islamic Countries History, Text and Comparative Analysis Law, h. 45-46. 
Di Syria, wanita berhak bersuara dalam pemilihan umum dengan hak penuh dengan menduduki jabatan strategis dalam pemerintahan. Singkatnya, kaum wanita diberikan kesempatan yang luas untuk memperoleh pendidikan dan menjalankan pelbagai profesi. Syria adalah negeri Muslim yang mencapai $80 \%$ penduduknya beragama Islam. ${ }^{39}$ Negara ini paling pertama membatasi praktik poligami dengan menetapkan larangan menikahi istri lebih dari satu jika tidak mampu membiayai. Dekrit 59 tahun 1953 ayat (17) tersebut menyatakan bahwa hakim berhak menolak izin seorang laki-laki yang telah menikah untuk menikahi wanita lain jika ternyata lakilaki itu tidak mampu memberikan nafkah dua orang istri. ${ }^{40}$

Beberapa ahli hukum Syria berpendapat bahwa syarat yang ditetapkan Alquran 4: 3 harus dipandang sebagai persyaratan hukum positif yang mendahului pelaksanaan poligami. Ketetapan tersebut dipaksakan sedemikian rupa oleh pengadilan dengan kentuan bahwa suami yang hendak kawin lagi dengan istri berikutnya disyaratkan harus mendapat izin dari pengadilan. Siapa saja yang melanggar undang-undang ini di anggap bersalah dan dikenakan saksi hukum oleh pengadilan. ${ }^{41}$

Oleh karena itu, mereka melangkah lebih jauh dengan melarang sama sekali poligami karena di anggap bertentangan dengan penjelasan Alquran. Pada dasarnya, modernisasi hukum keluarga bertujuan untuk meningkatkan status wanita dan memperkuat hak-hak keluarga anggota inti atas hak-hak keluarga yang lebih besar. Jadi tampak bahwa tindakkan hukum yang telah ditetapkan untuk menyelaraskan perubahan sosial sesuai perkembangan ilmu pengetahuan dan teknologi dengan roh syariat Islam yang berdemensi ruang dan waktu. ${ }^{42}$

\section{Sanksi Poligami di Malaysia}

Berdasarkan UU Malaysia tentang boleh atau tidaknya seorang laki-laki melakukan poligami, ada tiga hal penting dibicarakan: syarat-syarat, alasan-alasan pertimbangan boleh tidaknya poligami, dan prosedur. Adapun syarat yang harus dipenuhi, undang-undang keluarga Malaysia mengharuskan adanya izin terlebih dahulu secara tertulis dari hakim. Hanya saja dalam rinciannya, sedikit perbedaan yang secara garis besar

\footnotetext{
${ }^{39}$ Don Peretz, The Middle East Today, Edisi IV, h. 396.

${ }^{40}$ Tahir Mahmood, Personal Law in Islamic Countries History, Text and Comparative Analysis Law, h. 144.

${ }^{41}$ Saifullah, "Poligami dalam Struktur Keluarga Muslim", dalam Mimbar Hukum, Nomor 51, (2001), h.72.

${ }^{4}$ Saifullah, "Poligami dalam Struktur Keluarga Muslim", dalam Mimbar Hukum, Nomor 51, (2001) h.72.
}

dapat dikelompokan menjadi dua. Pertama, yang merupakan kelompok mayoritas, poligami tanpa izin lebih dahulu dari pengadilan tidak boleh didaftarkan. Kedua, poligami tanpa izin dari pengadilan boleh didaftarkan dengan syarat lebih dahulu membayar denda atau menjalani hukuman yang telah ditentukan.

Hukuman yang dimaksud diatur oleh UU Serawak dan UU Kelantan. UU Serawak pasal 21 ayat 1, terdapat kalimat "maka perkawinan itu hanya boleh didaftarkan di bawah ordinan ini termaktub kepada seyksen 125 ". Kalimat tersebut sebagai ganti kalimat "maka perkawinan itu tidak boleh didaftarkan di bawah Enagmen ini”, yang ada dalam pasal UU yang tidak membolehkan pendaftaran secara mutlak tanpa izin lebih dahulu dari pengadilan. Adapun maksud seksen 125 yang ada dalam UU Serawak adalah hukuman bagi orang yang melakukan poligami tanpa izin dari pengadilan lebih dahulu, yakni hukuman denda maksimal 3.000 ringgit atau maksimal penjara dua tahun. Sedangkan UU Kelantan pasal 19, ada tambahan "perkawinan itu boleh di daftarkan enagmet ini, tertakluk pada denda tidak lebih dari 300 ringgit atau penjara maksimal satu bulan". Karena itu ada perbedaan hukuman antara UU Serawak dan UU Kelantan. UU Serawak denda 1.000 ringgit atau penjara enam bulan, sementara Kelantan denda 300 ringgit atau penjara 1 bulan. ${ }^{43}$

Dasar pertimbangan pengadilan untuk memberi izin atau tidak, dilihat dari pihak istri dan suami. Alasan-alasan dari pihak istri adalah: (1) kemandulan; (2) karena keuzuran jasmani; (3) karena tidak layak dari jasmani untuk bersetubuh; (4) sengaja tidak mau memulihkan hak-hak persetubuhan; atau (5) gila.

Sedangkan pertimbangan dari pihak suami adalah: (1) mampu secara ekonomi untuk menanggung kebutuhan istri-istri dan anak keturunan; (3) berusaha untuk adil di antara para istri; (3) perkawinan itu tidak menyebabkan bahaya tehadap agama, nyawa, badan, akal pikiran atau harta benda istri yang telah lebih dahulu dinikahi; (4) perkawinan itu tidak akan menyebabkan turunnya martabat istri-istri atau orang yang terkait dengan perkawinan, langsung atau tidak. ${ }^{44}$

Penulis menilai secara umum, isi perundangundangan Malaysia tentang poligami, sama dengan

\footnotetext{
${ }^{43}$ Khoiruddin Nasution, "Status Wanita di Asia Tenggara: Studi terhadap Perundang-undangan Perkawinan Muslim Kontemporer di Indonesia dan Malaysia," Disertasi. Yogyakarta 2001, h. 150.

${ }^{44}$ Lihat UU Negeri Sembilan pasal 23 (4) a, c, d, dan e. Untuk jelasnya lihat Khioruddin Nasution, Khoiruddin Nasution, "Status Wanita di Asia Tenggara: Studi terhadap Perundang-undangan Perkawinan Muslim Kontemporer di Indonesia dan Malaysia," Disertasi. Yogyakarta 2001, h. 150.
} 
perundang-undangan Indonesia, yaitu berusaha mengatur agar laki-laki yang melakukan poligami harus disertai beberapa persyaratan. Pertama, mampu secara ekonomi menghidupi dan mencukupi seluruh kehidupan (sandang, pangan, dan papan) keluarga yaitu istri-istri dan anak-anak. Kedua, mampu berlaku adil terhadap istri-istrinya sehingga istri-istrinya dan anakanak dari suami poligami tidak disia-siakan. Akan tetapi di Kelantan, salah satu negara bagian di Malaysia, hukum keluarga yang berlaku belum beranjak dari konsep tradisional.

\section{Sanksi Poligami di Indonesia}

Dasar dan prinsip perkawinan di Indonesia adalah monogami. Hal ini tercatum dalam UU Nomor 1 Tahun 1974. Namun, masih ada dispensasi untuk melangsungkan perkawinan sampai maksimal 4 orang, ${ }^{45}$ dengan persetujuan pengadilan setelah izin dari istri sedangkan PNS diberikan izin apabila memenuhi sekurang-kurangnya salah satu syarat alternatif, dan ketiga syarat kumulatif. ${ }^{46}$ Syarat-syarat alternatif adalah: (1) Istri tidak dapat menjalankan kewajibannya sebagai istri; (2) Istri mendapat cacat badan yang tidak dapat disembuhkan; (3) Istri tidak dapat melahirkan keturunan. ${ }^{47}$

Sedangkan syarat- syarat kumulatif sebagai berikut: (1) Ada persetujuan tertulis dari istri; (2) Adanya kepastian bahwa suami mampu menjamin keperluan hidup istri dan anak- anak mereka; (3) Ada jaminan tertulis bahwa suami akan berlaku adil. ${ }^{48}$

Untuk membuktikan kemampuan suami dalam menjamin keperluan hidup keluarga adalah dengan melihat surat keterangan mengenai penghasilan suami yang ditandatangani bendahara tempat bekerja atau surat keterangan lain yang dapat diterima di pengadilan.

Oknum yang melanggar aturan-aturan poligami tersebut dianggap melanggar peraturan yang berlaku dan dapat dihukum dengan hukuman denda setinggitingginya tujuh ribu lima ratus rupiah. Jumlah hukuman denda itu harus dilihat dari nilainya bukan dari jumlahnya. PNS yang beristri lebih dari seorang tanpa izin dapat dihukum dengan empat kemungkinan:

45 UU no. 1 Tahun 1974 pasal 3 ayat-ayat 2 menyatakan, Pengadilan dapat memberikan izin soerang suami untuk beristri lebih dari seorang apabila dikehendaki oleh pihak-pihak yang bersangkutan.

${ }^{46}$ PP no. 10 tahun 1983 pasal 10 ayat 1.

${ }^{47}$ Pernyataan ini dapat dilihat pada UU no. 1 tahun 1974 pasal 4 ayat 2, PP no. 9 tahun 1975 pasal 41 huruf a, PP no. 10 tahun 1983 pasal 10 ayat 2 , dan KHI pasal 57.

${ }^{48}$ UU no. 1 tahun 1974 pasal 5, PP no. 9 tahun 1975.
(1) penurunan pangkat setingkat lebih rendah; (2) pembebasan jabatan; (3) pemberhentian dengan hormat tidak dengan atas permintaan sendiri sebagai PNS; (4) pemberhentian tidak dengan hormat sebagai PNS. ${ }^{49}$ PNS wanita yang menjadi istri kedua, ketiga, keempat dari seorang pria maka diberhentikan tidak dengan hormat sebagai PNS. ${ }^{50}$

Penulis menganggap perundang-undangan perkawinan Indonesia tentang poligami berusaha mengatur agar laki- laki yang berpoligami memenuhi syarat sebagai berikut: (1) mampu secara ekonomi dan mencukupi seluruh kebutuhan keluarga; (2) mampu berlaku adil terhadap istri-istrinya.

Dengan demikian perundang-undangan Indonesia terlihat berusaha menghargai istri sebagai pasangan hidup suami. Buktinya untuk poligami suami harus lebih dahulu ada persetujuan dari istri. Untuk itu ini perundang-undangan Indonesia memberikan kepercayaan sepenuhnya kepada hakim di Pengadilan Agama. Jadi, perundang-undangan Indonesia mengenai poligami, meskipun Alquran jelas mengizinkan seorang laki-laki menikah lebih dari satu, namun perundangundangan Indonesia melarangnya. Pelarangan semacam itu karena kerugiannya (mafsadah) lebih besar daripada keuntungannya (mashla $\underline{h} a h) .{ }^{51}$ Dengan demikian, undang-undang yang dibuat oleh pemerintah ditempatkan mengungguli naskah-naskah klasik fikih.

\section{Analisis Perbandingan}

Berdasarkan perundang-undangan di negara Tunisia, Pakistan, Mesir, Syria, Malaysia, dan Indonesia yang menjadi objek dalam tulisan ini, dilakukan analisis perbandingan vertikal, horisontal, diagonal, dan metode pembaruan.

Pertama, perbandingan vertikal. Secara umum, praktik poligami tidak pernah dilarang pada zaman Nabi Saw., apalagi diberi sanksi pelakunya. Hal ini dapat dilihat dalam fikih empat mazhab. Sanksi pelanggaran poligami di negara-negara Muslim memang tidak seragam. Namun, dibandingkan dengan ketentuan fikih Islam, maka harus diakui bahwa terdapat beberapa perbedaan atau keberanjakan yang sangat signifikan. Hal ini sedikitnya ada dua segi keberanjakan yang dapat dihimpun, yaitu: (1) Keberanjakan pada level status

\footnotetext{
${ }^{49}$ PP no. 30 pasal 6 ayat 4 tahun 1980.

${ }^{50}$ PP no. 45 tahun 1990 pasal 15 ayat 2 dengan tegas menyatakan PNS wanita yang melanggar ketentuan pasal 4 ayat 2 dijauhi hukuman disiplin yaitu pemberhentian tidak dengan hormat.

${ }^{51}$ M. Atho Mudzhar, Fatwa-fatwa Majelis Ulama Indonesia Studi tentang Pemikiran Hukuman Islam di Indonesia 1975-1988, (Jakarta: INIS, 1993), h. 100.
} 
yang diakibatkannya. Hal ini berhubungan dengan harta gono gini dan kewarisan. (2) Keberanjakan pada tingkat implikasi kepada ketentuan hukum yang terkait lainnya, baik dalam nafkah, maupun kewarisan.

Jadi, dapat dipahami bahwa apabila seorang dihadapkan dengan ketentuan-ketentuan fikih, maka fenomena ini sama sekali baru dan tidak pernah ada sebelumnya. Penulis berpendapat bahwa hal ini lebih bersifat menentang ketentuan nash. Namun, dalam perkembangannya secara perlahan-lahan praktik poligami dilarang. Hal ini adalah untuk menyelaraskan perubahan sosial yang terjadi seiring dengan perkembangan ilmu pengetahuan dan teknologi dengan roh syariat Islam yang berprinsip pada dimensi ruang dan waktu.

Sebagian dari negara-negara Muslim dunia masih ada yang melakukan praktik poligami dan memudahkannya siapa saja yang menginginkannya. Hal ini berdasarkan pada konsepsi lama yang berbeda dengan situasi zaman yang mutakhir. Keberanjakan yang lebih signifikan sebenarnya terjadi pada tingkat implikasi terhadap ketentuan hukum lain yang terkait, terutama dalam hal harta bersama.

Kedua, perbandingan horisontal. Mayoritas perundang-undangan perkawinan Muslim kontemporer mempersulit berpoligami, hanya cara dan metode yang digunakan berbeda-beda antara satu negara dengan negara lainnya. Perbedaan ini di samping karena faktor sosial yang berbeda, juga karena perbedaan kebutuhan dan tuntutan. Sebagai tambahan, perundang-undangan satu atau sejumlah negara dapat juga dipengaruhi isi atau aturan tentang poligami di negara-negara lain. Pengaruh tersebut menjadi faktor lain dalam merumuskan aturan poligami. Larangan poligami dengan pelbagai sanksinya adalah suatu pembaruan yang sudah lama menjadi tuntutan. Sanksi poligami tidak pernah dipraktikkan pada masa Rasulullah Saw. sampai masa sahabat R.a.. Ketentuan yang berlaku di negara-negara yang disebutkan merupakan regulatory atau campur tangan manusia atau penguasa yang merupakan keberanjakan dari hukum Islam dan sangat sesuai dengan semangat syariat.

Poligami adalah hal yang tidak mungkin diizinkan dewasa ini dan tidak mungkin dilakukan seorang yang mempunyai pikiran benar. Keluarga adalah tonggak masyarakat dan keluarga yang baik apabila adanya saling menghormati antara pasangan. Salah satu upaya untuk saling menghormati dan menghargai adalah nikah monogami. Karena itu, monogami bukan hanya ingin mengangkat harkat dan martabat wanita, tetapi lebih dari itu adalah menciptakan saling menghargai dan menghormati antara pasangan (suami dan istri) sebagai usaha maksimal untuk melahirkan anak-anak yang baik. Adapun poligami Nabi Saw. adalah sebelum adanya tauhid. ${ }^{52}$ Begitu pula poligami Nabi Saw. Muhammad harus dilihat dan dipertimbangkan kondisi kapan beliau melakukannya. Ternyata selama 28 tahun dari umur perkawinannya, beliau monogami dengan Khadijah. Beliau melakukan poligami sepeninggal Khadijah karena tuntutan politik dan sosial untuk mencapai ketentraman masyarakat. Sebagaimana keberanjakan yang dapat dilihat, yaitu pada tingkat prosedur nilai sanksi pelanggaran hukum poligami adalah berbeda dari setiap negara. Hal ini disebabkan karena latarbelakang sosio-historis dan politiknya yang berbeda-beda pula.

Dalam kaitan ini, maka dapat dipahami bahwa sanksi hukum pelanggaran poligami berdasarkan undang-undang hukum keluarga di Tunisia, Pakistan, Mesir, Syria, Malaysia dan Indonesia menunjukkan sisi yang berbeda-beda antara satu dengan yang lainnya. Upaya tersebut untuk menghapus praktik poligami secara gradual sedangkan urutan negara berturut-turut Tunisia, Pakistan, Mesir, Syria, Malaysia dan Indonesia adalah-menurut hemat penulis_urutan keradikalan yang dimliki oleh setiap negara yang dibahas dalam tulisan ini.

Ketiga, perbadingan diagonal. Analisis pada bagian ini dimaksudkan untuk melihat beberapa keberanjakan secara vertikal-konseptual tentang sanksi pidana pelanggaran larangan poligami dan pelbagai keberagamannya secara horisontal di pelbagai negara Muslim sekaligus. Kedua variabel ini disatukan menjadi satu titik dalam bentuk garis diagonal.

Apabila diringkas tentang pola dan alasan yang mendukung pola masing-masing dalam melarang atau mempersempit kemungkinan poligami, maka akan tergambar sebagai berikut: (1) Tunisia yang melarang poligami mendasarkan pada mustahilnya seorang suami berlaku adil terhadap istri-isrinya, padahal kriteria itu yang menjadi syarat mutlak bolehnya poligami. Konteks dari alasan pembaruan yang dilakukan di Tunisia sesuai dengan ajaran Islam, tidak seperti Turki yang mengadopsi sistem hukum Eropa. (2) Syria dan Mesir membatasi berdasar pada kekhawatiran kemampuan ekonomi. Konteksnya mugkin adalah fakta yang ada di Mesir bahwa kebanyakan anak terlantar diakibatkan oleh praktik poligami. Laki-laki

\footnotetext{
${ }^{52}$ Leila Ahmed, Women and Gender in Islam, Historical Roots of a Modern Debate, (London: Yale university Press, 1992), h. 42-52.
} 
yang berpoligami dianggap tidak mampu untuk mencukupi nafkah satu keluarga saja. Karena itu usaha membatasi bolehnya poligami adalah sebagai usaha menghindari kasus yang sama di masa yang akan datang. (3) Indonesia dan Malaysia secara umum pada kelompok yang menganggap poligami itu harus ada izin dari pengadilan. Misalnya dari sisi pembuktian kemampuan ekonomi dan pembuktian alasan hukum, aturan Indonesia terkesan lebih ketat dan lebih rinci di bandingkan Malaysia.

Sebagian besar perundang-undangan Perkawinan Muslim kontemporer mempersulit berpoligami, hanya cara dan metode yang digunaka berbeda-beda antara satu negara dengan negara lainnya. Perbedaan ini di samping karena faktor sosial yang berbeda, juga karena perbedaan kebutuhan dan tuntutan. Sebagai tambahan, perundang-undangan satu atau sejumlah negara dapat juga mempengaruhi isi atau aturan tentang poligami di negara-negara lain. Karena itu, pengaruh negara tertentu menjadi faktor dalam merumuskan aturan poligami.

Keempat, perbandingan metode pembaruan. Keenam negara yang disebutkan di atas telah melakukan pembaruan terhadap aturan-aturan tentang sanksi pidana pelanggaran poligami yang selama ini telah eksis di dalam hukum keluarga tradisional yang dianut oleh masing-masing negara. Masing-masing negara tersebut tidak menolak sanksi pelanggaran poligami, namun telah menetapkan peraturan-peraturan yang bersifat regulatory yang sangat ketat. Yaitu dengan harus membayar sanksi bagi pelanggar ketentuan-ketentuan yang bersifat regulatory tadi.

Aturan tersebut dipahami bahwa, pelbagai keberanjakan tersebut di atas adalah mempergunakan metode ekstra-doktrinal, intra-doktrinal, regulatory, dan kodifikasi. Tunisia melakukan pembaruan hukum Islam dalam hal sanksi poligami dengan metode intra dan extra-doctrinal reform dan kodifikasi. Sedangkan Pakistan, Mesir, Syria, Malaysia, dan Indonesia menggunakan reformasi yang bersifat intra-doctrional reform, regulasi reform dan kodifikasi. Klasifikasi ini bisa saja diwawancarakan melihat dalam banyak halIndonesia, Syria, dan Pakistan mungkin bisa melakukan upaya yang masuk kategori extra-doctrional reform, namun bisa juga adanya materi radikal dalam undangundang hukum keluarga Tunsia terkait dengan larangan poligami beserta saksinya yang memunjurkan bahwa undang-undang tersebut sangat radikal yang berbeda dari undang-undang negara lainnya.

Dengan menggunakan pengelompokkan yang ditawarkan oleh Tahir Mahmood yaitu; (1) boleh poligami secara mutlak; (2) poligami dapat menjadi ancaman cerai; (3) poligami harus ada izin dari pengadilan; (4 pembatasan poligami lewat kontrol sosial; (4) poligami dilarang secara mutlak: (5) dikenakan hukuman bagi yang melanggar aturan poligami, ${ }^{53}$ kita dapat membuat penilaian-penilaian tentang mana yang progresif, mana yang evolutif, dan mana yang resistentif terhadap pembaruan UU Hukum Keluarga negara-negara tersebut. Pengelompokkan ini menunjukkan bahwa semakin besar angka maka akan semakin pregresif, sementara semakin kecil angka maka ia semakin resisten. Kebolehan poligami secara mutlak adalah mewakili wacara pemikiran, tradisional yang kolot sementara adanya sanksi hukuman bagi yang melanggar aturan poligami mewakili pemikiran progresif.

\section{Penutup}

Perubahan pemikiran hukum Islam yang dituangkan dalam bentuk undang-undang itu seringkali juga bertentangan dengan apa yang tertuang dalam kitabkitab fikih sebagai literatur hukum baku. Sanksi pelanggaran poligami adalah masalah yang telah dituangkan dalam pelbagai hukum keluarga di dunia Islam yang semuanya tidak tercantum atau bahkan kadang bertentangan dengan kitab-kitab fikih.

Dengan menggunakan pengelompokkan yang ditawarkan oleh Tahir Mahmood di atas, akhirnya dapat dilihat urutan keradikalan dari enam negara dalam tulisan ini, yaitu: Tunisia, Pakistan, Mesir, Syria, Indonesia, dan Malaysia. Hal ini dapat dipahami bahwa urutan ini kira-kira dilihat dari undang-undang negara tersebut yang telah diperbaharui dari ketentuan dalam mazhab fikih.

Status hukum poligami di Tunisia, Pakistan, Mesir, Syria, Malaysia dan Indonesia, menunjukkan sisi-sisi yang berbeda antara satu dengan lainnya. Meskipun harus diakui pemahamannya mungkin disederhanakan menjadi boleh dan tidak boleh, namun muara akhir dari undang-undang ini belum secara definif mengarah ke sana dan masih mengambang. Upaya untuk meminimalisasikan atau bahkan menghapus praktik ini ternyata belum tuntas. Bahkan masih didapatkan undang-undang yang membolehkan poligami tanpa ketentuan yang jelas sehingga mungkin dapat dimanipulasi pelaksanaannya.

\footnotetext{
${ }^{53}$ Tahir Mahmood, Personal Law in Islamic Countries History, Text and Comparative Analysis Law, h. 275-278.
} 
Demikian sekilas perbandingan sanksi-sanksi pelanggaran poligami di negara-negara dunia Islam. Tema yang sangat besar dan luas menyebabkan kesimpulan yang diambil masih bias didiskusikan lebih lanjut. Dalam konteks inilah, para pembaca dituntut mengeksplorasi lebih lanjut. Perlu dicatat pula bahwa semangat reaktualisasi hukum Islam dalam bidang hukum keluarga umumnya adalah melindungi dan memperbaiki kedudukan wanita serta melindungi anak-anak. []

\section{Pustaka Acuan}

\section{Buku dan Artikel}

Alami, Dawoud L. dan Doreen Hinchcliffe, Islamic Marriage and Devorce Laws of Arab World, London: Kluwer Law Internasional, 1996.

Ahmed, Leila, Women and Gender in Islam, Historical Roots of a Modern Debate. London: Yale university Press, 1992.

Alami, Dawoud L. dan Doreen Hinchcliffe, Islamic Marriage and Divorce Laws of Arab World, London: Kluwer Law Internasional, 1996.

Allat, Antony, "Introduction", dalam Chibi Mallat dan Jane Cannors (ed.), Islamic Family Law, USA: Graham and Rotman, 1990.

Anderson, J.N.D, Law Reform Law Reform Law Reform in Muslim Word, London : Athlone Press, 1976.

, Islamic Law in Modern World, London: Oxford University Press, 1995.

al-Hafidz Abi Abdillah Muhammad Bin Yasid AlQuzwiniy, Sunan Ibnu Majah, Juz I, Beirut: Dar alQurub al-Ilmiah, t.th.

Hesting, James, Dictionary of Bible, New York: Charles Scribner's Sons, 1963.

al-Imam 'Alau al-Din Abi Bakar bin Mas'ud al-Kasani, Kitab Babai'u al-Sanai'u fi Tartib al-Sharani, cet. I, Beirut: Dar al-Fikr, 1996.

Imarah, Muhammad, Al-Imam Muhammad Abduh: Mujaddid Al-Islam, ttp, 1981.

Lapidus, Ira M, Sejarah Sosial Umat Islam, Jakarta: Rafa Grafindo, 1996.

Mahmood, Tahir, Personal Law in Islamic Countries History, Text and Comparative Analysis, New Delhi: Academy of Law and Religion, 1987.

Personal Law in Islamic Countries, New Delhi: Academi of Law and Relegion, 1987.

, Family Law Reform in the Muslim Wold, Bombay: N. M. Tripathi, 1972.
Mehdi, Rubya, The Islamization of The Law in Fakistan, Richmond: Curzon Press, 1994.

Mudzhar, M. Atho The Status of Women in Islam and Muslim Societies (A Sociological Approach), Artikel Seminar Internasional "Islam and Humanism", IAIN Walisongo Semarang, 5- 8 November 2008.

"Letak Gagasan Reaktualisasi Hukum Islam Munawir Syadzali di Dunia Islam", dalam Kontekstualisasi Ajaran Islam 70 Tahun Munawir Syadzali, (Jakarta: Paramadina, 1995.

Fatwa-fatwa Majelis Ulama Indonesia Studi tentang Pemikiran Hukuman Islam di Indonesia 1975-1988, Jakarta: INIS, 1993.

Muhsin, Amina Waduud, Qur'an And Women, Kuala Lumpur. Fajar Bhakti SDN, 1994.

Nasution, Khoirudidin, "Status Wanita di Asia Tenggara: Studi terhadap Perundang-Undangan Perkawinan Muslim Kontemporer di Indonesia dan Malaysia," Disertasi UIN Yogyakarta, 2001.

Nasir, Jamal J., The Statute of Women Under Islamic Law, London: Graham And trotman, 1990.

Peretz, Don, The Middle East Today, Edisi IV, New York: Praeger, 1983.

Raga, El-Nimr', "Perempuan dalam Hukum Islam," dalam Mai Yamani (ed), Feminisme dan Islam, terj. Purwanto, Jakarta: IKAPI, 2000.

Rahman, Fazlur, The Controversi Over Muslim The Family Law dalam South Asean Politics and Religions, New Jersey: Princeton University Press, 1996.

Islam and Modernity: Transformation of an Intellectual Tradition, Chicago: The University of Chiago Press, 1982.

, "A Survey of Modernization of Muslim Family Law", dalam Internasional Journal Middle East Study, Vol. 11, 1980.

Saifullah, "Poligami dalam Struktur Keluarga Muslim," dalam Mimbar Hukum, Nomor 51, tahun 2001.

Shihab, M. Quraish, Wawasan Alquran, Bandung: Mizan, 1997.

Vatin, Jean Claude "Revival in the Magrib: Islam as an Alternative Political language," dalam Ali Hilal E. Dessouki, Islamic Resurgence in the Arab World, USA: Praeger Publishers, 1982.

Yamani, Mai (ed), Feminisme dan Islam, diterjemahkan oleh Purwanto, Jakarta: IKAPI, 2000.

Ziadeh, Farhat J. Lawyer: The Role of Law and Liberalism in Modern Egypt, California: Stanford University, 1968. 


\section{Peraturan Perundang-undangan}

UU No. 1 Tahun 1974 tentang Perkawinan

PP nomor 10 tahun 1983 tentang bagi Izin Perkawinan dan Perceraian Pegawai Negeri Sipil (PNS) Republik Indonesia
PP nomor 45 tahun 1990 tentang Perubahan atas Peraturan Nomor 10 tahun 1983 tentang Izin Perkawinan dan Perceraian bagi Pegaiwai Negeri Sipil (PNS) Repbulik Indonesia

PP nomor 30 tahun 1980 tentang Peraturan Disiplin Pegawan Negeri Sipil (PNS) Republik Indonesia 